\title{
Morphological characterization of the Azikheli buffalo in Pakistan
}

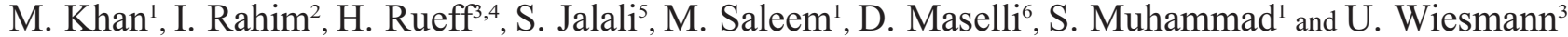 \\ ${ }^{I}$ Directorate General of Livestock and Dairy Development of Khyber Pakhtunkhwa, Peshawar, Pakistan; ${ }^{2}$ Mountain Society Research \\ Centre, University of Central Asia, Bishkek, Kyrgyzstan; ${ }^{3}$ Centre for Development and Environment, University of Bern, Switzerland; \\ ${ }^{4}$ School of Geography and the Environment, University of Oxford, UK; ${ }^{5}$ Department of Animal Sciences, Quaid-i-Azam University, \\ Islamabad, Pakistan; ' ${ }^{6}$ Senior Policy Advisor and Focal Point, Climate Change and Environment Network c/o Global Programme \\ Climate Change GPCC, Corporate Domain Global Cooperation, Swiss Agency for Development and Cooperation SDC, Federal \\ Department of Foreign Affairs FDFA, Freiburgstrasse 130 CH- 3003 Bern, Switzerland
}

\begin{abstract}
Summary
This study aims to characterize Azikheli, an undocumented buffalo breed, in its home tract (Khwazakhela, Swat, Pakistan) under traditional farming conditions. For this purpose, 108 buffalo cows and 27 bulls were randomly selected. Mean, standard error, Student's $t$ test and Chi-square test were used for various comparisons. The results show that the majority of animals have a brown coat colour. Cows have significantly higher heart girths, longer horns, longer necks and wider faces at the level of the eyes than bulls, whereas bulls have significantly longer bodies, longer ears, thicker horns, thicker necks and larger hooves than cows. Horns are flat laterally, directed backwards and then slightly upwards without twisting, leading to a sickle to semi-sickle appearance. Owing to its small body size and brown coat colour, the breed is well adapted to mountain slope grazing and thrives well away from swamps. Its adaptation to mountainous ecosystems warrants its in situ conservation.
\end{abstract}

Keywords: phenotypic, morphometric, characteristics, Azikheli buffalo breed, Pakistan

\section{Résumé}

Cette étude cherche à caractériser la race de buffle non documentée Azikheli dans son territoire d'origine (Khwazakhela, Swat, Pakistan) sous les conditions d'élevage traditionnelles. Pour ce faire, 108 bufflonnes et 27 mâles ont été sélectionnés au hasard. La moyenne, l'erreur type, le test de Student et le test du Khi-carré ont été utilisés pour faire plusieurs comparaisons. Les résultats montrent que la plupart des animaux ont un pelage brun. Les vaches ont, significativement, une circonférence thoracique plus grande, des cornes et des cous plus longs et une face plus large au niveau des yeux, par rapport aux mâles. Par contre, les mâles ont, significativement, des oreilles et des corps plus longs, des cornes et des cous plus gros et des onglons plus grands que ceux des bufflonnes. Les cornes partent horizontalement vers les côtés puis se dirigent vers l'arrière et finalement montent sans se tordre, ce qui fait que les cornes aient l'aspect d'une faucille ou demi-faucille. En raison de sa petite taille corporelle et de la couleur brune de son pelage, la race est bien adaptée au pâturage sur les flancs des montagnes et se développe bien en dehors des zones marécageuses. Son adaptation aux écosystèmes montagneux garantit sa conservation in-situ.

Mots-clés: caractéristiques phénotypiques et morphométriques, race de buffle Azikheli, Pakistan

\section{Resumen}

Este estudio pretende caracterizar el ganado Azikheli, una raza de búfalos no documentada, en su área de origen (Khwazakhela, Swat, Pakistán) y bajo condiciones de cría tradicionales. Con este fin, se seleccionaron aleatoriamente 108 búfalas y 27 machos. Se usaron la media, el error estándar, la prueba t de Student y la prueba Chi-cuadrado para realizar múltiples comparaciones. Los resultados muestran que la mayoría de los animales presentan una capa de color marrón. Las vacas tienen, significativamente, mayores circunferencias torácicas, cuernos y cuellos más largos y la cara más ancha a la altura de los ojos, en comparación con los toros. Sin embargo, los toros tienen, significativamente, cuerpos y orejas más largos, cuernos y cuellos más gruesos y pezuñas más grandes que las vacas. Los cuernos parten de forma horizontal hacia los lados para a continuación dirigirse hacia atrás y después ligeramente hacia arriba sin retorcerse, con lo que adquieren un aspecto de hoz o semi-hoz. Debido a su pequeño tamaño corporal y al color pardo de su capa, la raza está bien adaptada al pastoreo en las laderas de montaña y se desarrolla bien fuera de las zonas pantanosas. Su adaptación a ecosistemas montañosos garantiza su conservación in-situ.

Palabras clave: características fenotípicas y morfométricas, raza de búfalos Azikheli, Pakistán 


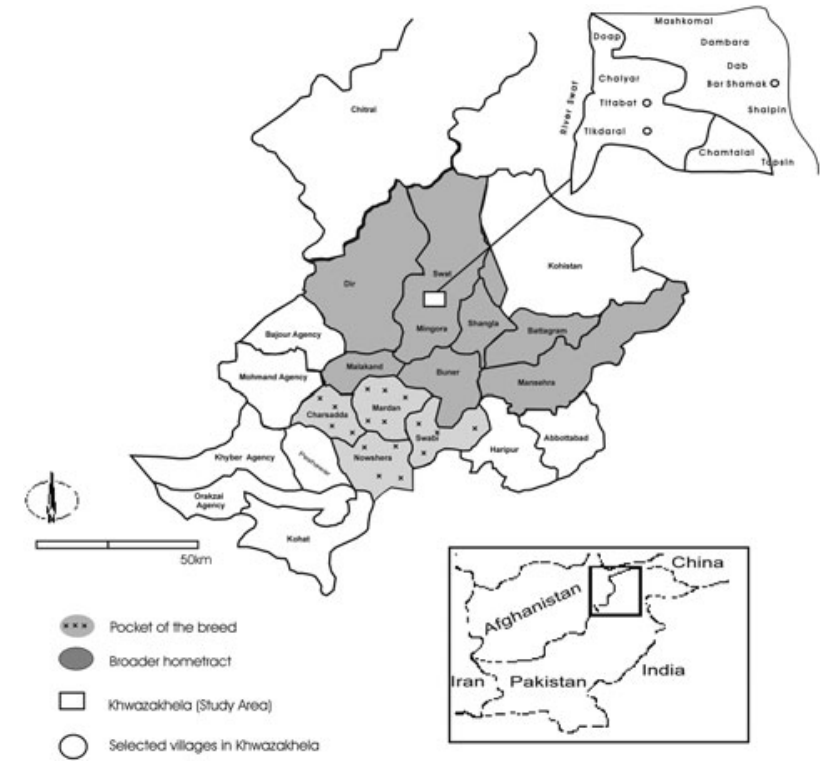

Figure 1. Map of the study area.

\section{Introduction}

Indigenous livestock breeds are known for their hardiness, disease resistance, survival on little inputs and adaptability to variable environments (Köhler-Rollefson et al., 2009). Such breeds are therefore believed to be more economically efficient than other breeds when raised in their home tract (Ayalew et al., 2003). Many indigenous livestock breeds are, however, on the verge of extinction because of their gradual dilution, as driven by market demands and inappropriate use of new breeding technology (Köhler-Rollefson et al., 2009). Limited awareness of the adaptive characteristics of indigenous livestock breeds owing to a lack of proper scientific documentation is one of the key reasons for such dilution (Hassen et al., 2007; Köhler-Rollefson et al., 2009).

There are quite a number of indigenous livestock breeds that still need to be scientifically documented and characterized to enable their conservation (Bhatia \& Arora, 2005). To make the conservation of indigenous breeds a reality and ensure sustainable use of their genetic diversity, it is particularly desirable that their phenotypic characteristics and performance be evaluated in their home tracts and under traditional management conditions (Zarate,
1996). Identification of specific breed attributes can also contribute to better use of these genetic resources by farmers (Mwacharo et al., 2006).

In Pakistan, the most thoroughly studied indigenous buffalo breeds are Nili-Ravi and Kundi, though 37 percent of the buffalo population has been categorized as non-descript (Khan et al., 2007). These non-descript breeds also include Azikheli, which is known for its adaptation to the mountain environment (Khan et al., 2011). The present investigation is thus designed to study the morphological (physical and morphometric) characteristics of Azikheli in its home tract under traditional management conditions.

\section{Materials and methods}

\section{Home tract and study area}

The Azikheli is named after its original home tract known as Azikhel (Khwazakhela union council). Khwazakhela, which covers an approximate area of $124 \mathrm{~km}^{2}$ and is one of several tributary valleys of the Swat River, has been chosen as the study area for this investigation (Figure 1). Khwazakhela has a mean temperature ranging from $-2{ }^{\circ} \mathrm{C}$ to $33^{\circ} \mathrm{C}$ and an average annual rainfall of 1400 to 1500 mm (Khan \& Atta-ur Rahman, 2010).

The broader home tract of the breed includes the watershed of the Swat River (Swat district) and the Panjkora River (Lower and Upper Dir districts), as well as the Shangla, Buner, Batagram, Manshera and Malakand districts, and covers approximately $20000 \mathrm{~km}^{2}$ and has an elevation range from 516 to $3314 \mathrm{~m}$ a.s.l. Pockets of the breed can also be found in the districts of Mardan, Charsadda, Nowshera and Sawabi as a result of buffalo transhumance that prevails in some farming communities.

\section{Sampling pattern}

Khwazakhela union council includes seven main villages. Three villages were randomly selected: Tikdarai, Tetabat and Bar Shamak (Figure 1). The number of cows (with at least one parturition) and bulls (aged 3 years or more, and which are used for breeding purposes) randomly selected from these villages is presented in Table 1. For the cows, measurements were made within 2-3 months

Table 1. Sampling pattern.

\begin{tabular}{lccccc}
\hline Name of village & $\begin{array}{c}\text { Total number } \\
\text { of households }\end{array}$ & \multicolumn{3}{c}{ Number of adult cows } & \multicolumn{2}{c}{ Number of adult bulls } \\
\cline { 3 - 5 } & & Total & $\begin{array}{c}\text { With at least } \\
\text { one parturition }\end{array}$ & $\begin{array}{c}\text { Randomly } \\
\text { selected }\end{array}$ & $\begin{array}{c}\text { Total } \\
\text { Randomly } \\
\text { selected }\end{array}$ \\
\hline Tikdharai & 248 & 992 & 252 & 36 & 22 \\
Tetabat & 218 & 872 & 220 & 36 & 18 \\
Bar Shamak & 211 & 844 & 214 & 36 & 16 \\
Total & 677 & 2708 & 686 & 98 & 56 \\
\hline
\end{tabular}


after parturition by using measuring tape according to Food and Agriculture Organization (1986).

Physical characteristics (colour of the body coat, forehead, eyelashes, eyes, horns, muzzle, forelegs, hind legs and hooves) were recorded for each selected animal, and measurements were taken for the heart girth (body circumference immediately posterior to the front leg), body length (distance from shoulder point to pin bone), height at withers (the vertical distance from the ground level to the highest point of withers) and at hip bone (the vertical distance from the ground level to the hipbone), width of head (between horns and between eyes), ear length (distance from the tip of the ear to the base of the ear), ear width (at the widest part of ear), face length (the distance between the head pol and muzzle), horn length (the distance from the tip of the horn to the base of the horn both along greater and smaller curvatures), horn circumference (at base, middle region and below tip), neck length (the distance from at the junction with shoulder to at the junction with head) and circumference (at the midway from the junction with shoulder and junction with head), loin length (distance from withers to last rib), chine (distance from last rib to hipbone), rump length (distance from hip to pin bone) and width (distance between the lateral surfaces of the tuber coxae), height of front leg below the knee (vertical distance from knee to the ground level), height of hind leg below hock (vertical distance from hock to the ground level),

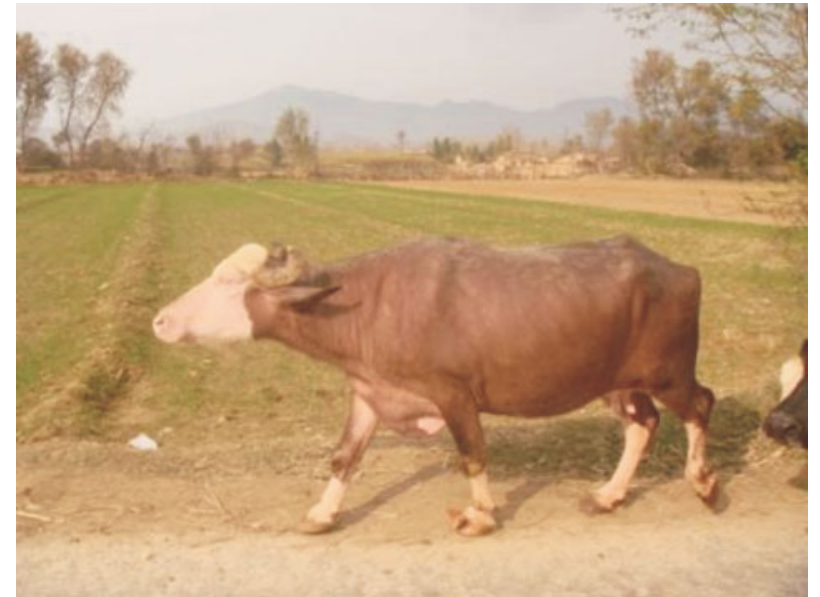

Figure 2. Azikheli cow.

height of pastern (vertical distance from pastern to ground level) and circumference of hoof and length of tail (distance from the tail drop to the tip of the tail).

\section{Statistical analysis}

Chi-square tests of independence were used to compare the physical characteristics of bulls and cows. Mean, standard error and Student's $t$ test were calculated for morphometric measurements of both sexes.

Table 2. Physical characteristics of Azikheli.

\begin{tabular}{|c|c|c|c|c|c|}
\hline Body part & Colour pattern $(\%)$ & Cow, $n=108$ & Bull, $n=27$ & Chi-square value & $P$-value \\
\hline \multirow[t]{4}{*}{ Coat } & Brown & 62.04 & 59.26 & $\chi_{(3)}^{2}=0.32$ & $>0.05$ \\
\hline & Black & 22.22 & 22.22 & & \\
\hline & Black and white & 11.11 & 14.82 & & \\
\hline & White & 04.63 & 03.70 & & \\
\hline \multirow[t]{3}{*}{ Forehead } & Completely white & 61.11 & 55.56 & $\chi_{(2)}^{2}=2.93$ & $>0.05$ \\
\hline & White-spotted & 29.63 & 29.63 & & \\
\hline & White extended to nose bridge & 09.26 & 14.81 & & \\
\hline \multirow[t]{4}{*}{ Eyelashes } & White & 50.00 & 44.44 & $\chi_{(3)}^{2}=0.45$ & $>0.05$ \\
\hline & Black & 27.78 & 29.64 & & \\
\hline & Brown & 17.59 & 22.22 & & \\
\hline & Reddish with black tinge & 04.63 & 03.70 & & \\
\hline \multirow[t]{2}{*}{ Eyes } & Shiny blue & 80.00 & 76.00 & $\chi_{(1)}^{2}=0.45$ & $>0.05$ \\
\hline & Black & 20.00 & 24.00 & & \\
\hline \multirow[t]{4}{*}{ Horns } & Completely brown & 34.26 & 29.63 & $\chi_{(3)}^{2}=0.54$ & $>0.05$ \\
\hline & Black & 51.85 & 51.85 & & \\
\hline & Brown with black tips & 09.26 & 11.11 & & \\
\hline & Black with brown tips & 04.63 & 07.41 & & \\
\hline \multirow[t]{4}{*}{ Muzzle } & White & 55.55 & 51.85 & $\chi_{(3)}^{2}=0.17$ & $>0.05$ \\
\hline & Black & 15.74 & 18.53 & & \\
\hline & Black and white & 14.81 & 14.81 & & \\
\hline & Black-pigmented to whitish-pigmented & 13.90 & 14.81 & & \\
\hline \multirow[t]{3}{*}{ Forelegs } & White below knee & 75.00 & 70.37 & $\chi_{(2)}^{2}=0.96$ & $>0.05$ \\
\hline & Completely white & 10.19 & 07.41 & & \\
\hline & Black and white & 14.81 & 22.22 & & \\
\hline \multirow[t]{3}{*}{ Hind legs } & White below hock & 65.74 & 59.26 & $\chi_{(2)}^{2}=0.41$ & $>0.05$ \\
\hline & Completely white & 14.82 & 18.52 & & \\
\hline & Black and white & 19.44 & 22.22 & & \\
\hline \multirow[t]{3}{*}{ Hoof } & Brown & 60.19 & 55.55 & $\chi_{(2)}^{2}=0.22$ & $>0.05$ \\
\hline & Black & 37.04 & 40.75 & & \\
\hline & Brown with black striation & 2.77 & 03.70 & & \\
\hline
\end{tabular}




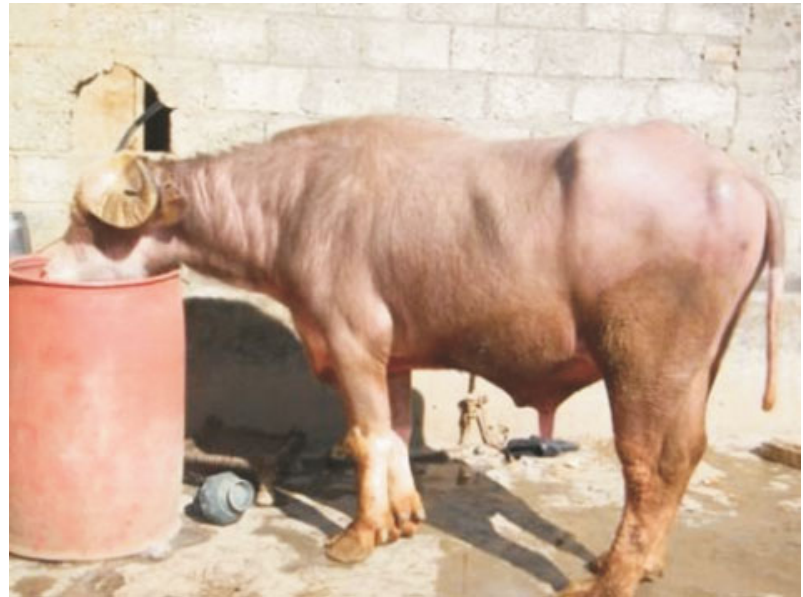

Figure 3. Azikheli bull.

Table 3. Mean values $( \pm \mathrm{SEM})$ of morphometric measurements (cm) of Azikheli.

\begin{tabular}{lcc}
\hline Variables & Cow & Bull \\
\hline Heart girth & $191.36 \pm 1.26$ & $177.68 \pm 3.76^{* * *}$ \\
Body length & $140.39 \pm 0.94$ & $147.89 \pm 2.60^{* * *}$ \\
Height at withers & $131.35 \pm 0.57$ & $130.01 \pm 0.78^{\mathrm{NS}}$ \\
Height at hip bone & $123.41 \pm 0.41$ & $124.08 \pm 0.67^{\mathrm{NS}}$ \\
Width of head between horns & $22.74 \pm 0.27$ & $22.15 \pm 0.47^{\mathrm{NS}}$ \\
Width of head between eyes & $20.37 \pm 0.13$ & $19.43 \pm 0.32^{* * *}$ \\
Ear length & $21.39 \pm 0.18$ & $22.80 \pm 0.23^{\mathrm{NS}}$ \\
Ear width & $16.46 \pm 0.12$ & $16.86 \pm 0.21^{\mathrm{NS}}$ \\
Face length & $52.45 \pm 0.2$ & $52.67 \pm 0.55^{\mathrm{NS}}$ \\
Horn length along greater curvature & $42.52 \pm 1.02$ & $35.7 \pm 1.36^{* * *}$ \\
Horn length along smaller curvature & $27.55 \pm 0.82$ & $21.62 \pm 0.68^{* * *}$ \\
Horn circumference at base & $22.60 \pm 0.22$ & $25.12 \pm 0.41^{* * *}$ \\
Horn circumference in middle region & $20.13 \pm 0.22$ & $20.83 \pm 0.31^{\mathrm{NS}}$ \\
Horn circumference below tip & $7.63 \pm 0.13$ & $7.13 \pm 0.21^{\mathrm{NS}}$ \\
Neck length & $42.57 \pm 0.37$ & $40.50 \pm 0.57^{*}$ \\
Neck circumference & $89.60 \pm 0.61$ & $97.32 \pm 1.81^{* * *}$ \\
Loin length & $35.97 \pm 0.36$ & $34.55 \pm 0.55^{\mathrm{NS}}$ \\
Chine & $45.95 \pm 0.54$ & $46.76 \pm 0.80^{\mathrm{NS}}$ \\
Rump length & $41.45 \pm 0.31$ & $42.03 \pm 0.39^{\mathrm{NS}}$ \\
Rump width & $51.03 \pm 0.37$ & $50.43 \pm 0.59^{\mathrm{NS}}$ \\
Height of front leg below knee & $30.34 \pm 0.25$ & $31.34 \pm 0.43^{\mathrm{NS}}$ \\
Height of hind leg below hock & $46.27 \pm 0.32$ & $47.51 \pm 0.38^{\mathrm{NS}}$ \\
Height of pastern & $5.92 \pm 0.11$ & $5.65 \pm 0.14^{\mathrm{NS}}$ \\
Hoof circumference & $71.39 \pm 1.04$ & $67.38 \pm 1.58^{\mathrm{NS}}$ \\
Tail length & & \\
\hline & & \\
\hline & &
\end{tabular}

NS, non-significant.

$* P<0.05, * * * P<0.01$

\section{Results}

\section{Physical characteristics}

No significant differences were observed between cows and bulls (Table 2). Figures 2 and 3 show examples of the Azikheli cow and bull, respectively.

\section{Morphometric characteristics}

Table 3 shows that Azikheli cows have a significantly larger heart girth, wider forehead, longer horns and longer neck than bulls. On the other hand, bulls have a significantly longer body, thicker horns and neck, and larger hooves than cows. Horns are flat laterally, and directed backwards and slightly upwards without twisting. The upward curve is variable and gives the horn a sickle or semi-sickle appearance. This is a specific characteristic of the Azikheli breed.

\section{Discussion}

Buffaloes show a variety of coat colours, with most riverine buffaloes being black to ashy grey (Soysal et al., 2007), while the coat colour of swamp buffaloes ranges from grey to completely black, with very few having a white coat (Miao et al., 2010). The common buffalo breeds of Pakistan are predominantly black (Khan et al., 2005) with only occasional occurrence of brown coats ( 8 percent) in Nili-Ravi and Kundi buffalo (Maqsood, 1980). A dark coat causes heat intolerance because it absorbs a great deal of solar radiation and this is one of the reasons why dark-coated breeds wallow in swamps (Marai \& Haeeb, 2010). The dominant brown coat colour (62.04 percent) in Azikheli seems to be an adaptation to the mountainous environment, where swamps are not available.

The farmers of the area prefer Sra Chargai (a brown coat colour with a completely white forehead) to Sra Tikai (a brown coat colour with a white spot on forehead).

The non-significant difference between the colour patterns of various body parts of the Azikheli cow and bull may be due to the prevalence of natural selective forces over social preferences in determining coat colour in bovines (Seo et al., 2007).

Information on morphological characteristics is helpful in ensuring effective management and conservation of animal

Table 4. Comparison of morphometric measurements (cm) of Azikheli and Nili-Ravi.

\begin{tabular}{lccr}
\hline Characteristics & \multicolumn{2}{c}{ Azikheli } & \multicolumn{2}{c}{ Nili-Ravi $^{\text {a,b }}$} & Bull & Cow \\
\cline { 2 - 4 } & Cow & $177.68 \pm 3.76$ & $215-225$ \\
Heart girth & $191.36 \pm 1.26$ & $147.89 \pm 2.60$ & $145-149$ \\
Body length & $140.39 \pm 0.94$ & $130.01 \pm 0.78$ & $125-135$ \\
Height at withers & $131.35 \pm 0.57$ & $159-165$ & $135-137$ \\
\hline
\end{tabular}

${ }^{\mathrm{a}}$ Khan, Younas \& Hanjra (1982), Ranjhan \& Pathak (1993), Borghese \& Moioli (2005).

${ }^{\mathrm{b}}$ Values for morphometric measurements of Nili-Ravi are in ranges. 
genetic resources with a view to obtaining phenotypically pure local genetic resources for future selection and breed improvement strategies (Yakubu et al., 2010). Berthouly et al. (2009) recorded heart girth, body length, height at withers, neck circumference, ear length and thorax depth as appropriate variables to differentiate the local Vietnamese swamp buffalo population from other buffalo breeds. For Pakistani buffalo breeds, such information is limited to heart girth, body length and height at withers, hence comparative measurements shown in Table 4 are limited to these three parameters.

Comparison of these parameters between the two breeds reveals that the body size of Azikheli is smaller than that of Nili-Ravi, a breed that is well adapted to life in the plains. Owing to their low maintenance requirements (Ibrahim \& Brannang, 2001), smaller animals are considered less susceptible to fodder shortages (Hall, 1998) and are able to move more easily and rapidly on mountain slopes (Ouma et al., 2004). As the Azikheli is native to mountain valleys with high seasonal fluctuations in the availability of feed resources, its smaller body size can be interpreted as an adaptive trait to fodder fluctuations, as well as to grazing in mountain terrain and transhumance. Sexual size dimorphism has been observed in the present study, with a longer body of the bull, whereas the cow has a large heart girth size and wider head at the eyes.

\section{Conclusion}

Given its small body size and brown coat colour, it appears that the breed is well adapted to mountain slope grazing and variable availability of feed resources. Differentiating characteristics of the Azikheli include the dominant brown coat colour and the sickle-shaped horns. In view of climate change and the likelihood of an increase in the frequency of extreme weather events in mountain regions in particular, livestock breeds like the Azikheli could prove to be a valuable resource for mountain dwellers in terms of adaptation to such weather extremes. The morphometric characteristics described here provide a basic description of the breed, but studies on genotypic characteristics and plans for in situ participatory conservation of the Azikheli are suggested measures to secure its appropriate conservation.

\section{Acknowledgements}

This study was conducted within the framework of the Joint Research Partnership funded by the Swiss National Science Foundation (SNSF) and the Swiss Agency for Development and Cooperation (SDC). It was also conducted within the framework of the Swiss National Centre of Competence in Research (NCCR) NorthSouth: Research Partnerships for Mitigating Syndromes of Global Change. The NCCR North-South is co-funded by SNSF and SDC, and the participating institutions.

\section{References}

Ayalew, W., Rischkowsky, B., King, J.M. \& Bruns, E. 2003. Crossbreds did not generate more net benefits than indigenous goats in Ethiopian smallholdings. Agricultural Systems, 76: 1137-1156.

Berthouly, C., Rognon, X., Van, T.N., Berthouly, A., Hoang, H.T., Bed'Hom, B., Laloe, D., Vu Chi, C., Verrier, E. \& Maillard, J.C. 2009. Genetic and morphometric characterization of a local Vietnamese Swamp Buffalo population. Journal of Animal Breeding and Genetics, 127: 1-11.

Bhatia, S. \& Arora, R. 2005. Biodiversity and conservation of Indian sheep genetic resources: an overview. Asian-Australasian Journal of Animal Science, 18: 1387-1402.

Borghese, A. \& Moioli, B. 2005. Buffalo breeds and management systems. In A. Borghese ed., Buffalo Production and Research, the State of the Art of Research, Development, Products and Market of Buffalo Species in the World, pp. 69-70, REU Technical Series 67, FAO Regional Office for Europe, Rome.

FAO. 1986. Animal Genetic Resources Data Banks. 2. Descriptor Lists for Cattle, Buffalo, Pigs, Sheep and Goats. FAO Animal Production and Health Paper 59/2, Food and Agriculture Organization of the United Nations, Rome (available at ftp://ftp.fao.org/docrep/fao/009/ ah760e/AH760E00.pdf).

Hall, S.J.G. 1998. Traditional livestock in semi-arid north eastern Zimbabwe: Mashona cattle. Tropical Animal Health and Production, 30: 351-360.

Hassen, F., Bekele, E., Ayalew, W. \& Dessie, T. 2007. Genetic variability of five indigenous Ethiopian cattle breeds using RAPD markers. African Journal of Biotechnology, 6: 2274-2279.

Ibrahim, A. \& Brannang, E. 2001. Growth performance of crossbred dairy cattle at Asella livestock Farm, Arsi Ethiopia. Ethiopian Journal of Science, 24: 35-49.

Khan, A.N. \& Atta-ur-Rahman. 2010. Causes and environmental impacts of flood hazards: a case study of sample villages, Swat valley, Pakistan. In: Proceedings of the 4th International Congress of the Islamic World Geographers (ICIW92010), University of Sistan and Baluchistan, Zahidan, Iran (14-16 April 2010).

Khan, B.B., Younas, M. \& Hanjra, S.H. 1982. Breeds and Types of Livestock in Pakistan. 2nd edition, Department of Livestock Management, University of Agriculture Faisal Abad, Pakistan, pp. 2-4.

Khan, B.B., Younas, M., Riaz, M. and Yaqoob, M. 2005. Breeds of Livestock in Pakistan. Department of Livestock Management, University of Agriculture, Faislabad, Pakistan, pp. 2-6.

Khan, M.S., Khan, M.A., Ahmad, S. \& Mahmood, S. 2007. Genetic resources and diversity in Pakistani sheep. International Journal of Agriculture and Biology, 9: 941-944.

Khan, M., Rahim, I., Rueff, H., Saleem, M., Maselli, D., Mohammad, S. \& Wiesmann, U. 2011. Conserving indigenous animal genetic resources as a coping strategy to adapt to climate change: the Azikheli buffalo in northern mountains of Pakistan. Livestock Research for Rural Development, 23, (available at http://www.lrrd. org/lrrd23/12/khan23246.htm)

Köhler-Rollefson, I., Rathore, H.S. \& Mathias, E. 2009. Local breeds, livelihood and livestock keepers' rights in South Asia. Tropical Animal Health and Production, 41: 1061-1070.

Maqsood, M. 1980. Development of Asian buffaloes "breeds and types". Journal of Animal Science, 2: 60-64.

Marai, I.F.M. \& Haeeb, A.A.M. 2010. Buffalo's biological functions as affected by heat stress: a review. Livestock Science, 127: 89-109. 
Miao, Y., Wu, G., Wang, L., Li, D., Tang, S., Liang, J., Mao, H., Luo, H. \& Zhang, Y. 2010. The role of MC1R gene in buffalo coat color Science China Life Science, 53: 267-272.

Mwacharo, J. M., Okeyo, A.M., Kamande, G.K. \& Rege, J.E.O. 2006 The small East African shorthorn zebu cows in Kenya. 1: linear body measurements. Tropical Animal Health and Production, 38 $65-74$.

Ouma, E., Abdulai, A., Drucker, A. \& Obare, G. 2004 Assessment of farmer preferences for cattle traits in smallholder cattle production systems of Kenya and Ethiopia. In Proceedings of the Deutscher Tropentag Conference on International Agricultural Research for Development, 5-7 October 2004, Berlin, Germany.

Ranjhan, S.K. \& Pathak, N.N. 1993. Text Book on Buffalo Production, 3rd edition, Vikas Publishing House, New Delhi, India.
Seo, K., Mohanty, R.T., Choi, T. \& Hwang, I. 2007. Biology of epidermal and hair pigmentation in cattle: a mini review. Veterinary Dermatology 18: 392-400

Soysal, M.I., Tuna, Y.T., Gurcan, E.K., Ozkan, E., Kok, S., Castellano, N., Cobanoglu, O. \& Barone, C.M.A. 2007. Anatolian water buffaloes husbandry in Turkey: preliminary results on somatic characterization. Italian Journal of Animal Science, 6 (Suppl. 2): 1302-1307.

Yakubu, A., Salako, A. E., Imumorin, I.G., Ige, A.O. \& Akinyemi, M. O. 2010. Discriminant analysis of morphometric differentiation in the West African Dwarf and Red Sokoto goats. South African Journal of Animal Science, 40: 381-387.

Zarate, A.V. 1996. Breeding strategies for marginal regions in the tropics and subtropics. Animal Research and Development, 43: 99-118 